\title{
Morphological and growth alterations on early development stages of Iridaea cordata (Rhodophyta) under different intensities of UVB radiation
}

Alteraciones morfológicas y de crecimiento en estados tempranos del desarrollo de Iridaea cordata (Rhodophyta) bajo diferentes intensidades de radiación UVB

\author{
Nelso P. Navarro ${ }^{1,2}$, Mauricio Palacios ${ }^{1}$, Andrés Mansilla ${ }^{1,3}$ and Jocelyn Jofre ${ }^{1}$ \\ ${ }^{1}$ Departamento de Ciencias y Recursos Naturales, Facultad de Ciencias, Universidad de Magallanes, Casilla 113-D, Punta Arenas, \\ Chile.navarro.nelso@gmail.com \\ ${ }_{2}^{2}$ Departamento de Botânica, Instituto de Biociências, Universidade de São Paulo, Rua do Matão 277, CEP 05508-090, Cidade \\ Universitária, Butantã, São Paulo, Brasil \\ ${ }^{3}$ Instituto de Ecología y Biodiversidad, Facultad de Ciencias, Universidad de Chile, Casilla 653, Santiago, Chile
}

\begin{abstract}
Resumen.- Este estudio describe los efectos de diferentes intensidades de radiación UVB sobre el crecimiento y la morfología de estados tempranos del desarrollo de Iridaea cordata en sus discos de fijación y gametofitos juveniles generados en laboratorio, así como sobre frondas juveniles colectadas en el Estrecho de Magallanes, Chile. Los experimentos fueron realizados durante 4 semanas en condiciones controladas de temperatura y fotoperíodo cuyos resultados fueron comparados con un tratamiento control (sin UVB). Los tratamientos con UVB provocaron despigmentación y disminución en el crecimiento de los germlings y no se observó la generación de primordios de frondas erectas, mientras que aquellos cultivados en ausencia de UVB desarrollaron frondas a partir de la segunda semana de cultivo. Los gametofitos juveniles generados en laboratorio presentan alteraciones morfológicas (menor número y tamaño de ramificaciones basales, curvatura de ápices, despigmentación y necrosis) y disminución del crecimiento en presencia de UVB. Las frondas juveniles colectadas en el Estrecho de Magallanes presentaron principalmente alteraciones morfológicas (curvatura de la fronda). Las alteraciones morfológicas observadas en frondas y gametofitos juveniles de $I$. cordata podrían ser interpretadas como defensa contra la radiación UVB reduciendo el área expuesta a esta radiación. Sin embargo, altos niveles de UVB podrían producir daños irreparables tal como la necrosis observada en gametofitos juveniles originados en laboratorio. Finalmente, los efectos de la UVB en los estados tempranos del desarrollo de $I$. cordata dependen de la irradiancia de UVB y el tiempo de exposición.
\end{abstract}

Palabras clave: Alga, crecimiento, germlings, Estrecho de Magallanes, morfología

\begin{abstract}
This study describes the effects of different intensities of UVB radiation on growth and morphology of early development stages of Iridaea cordata in germlings, young gametophytes originated in the laboratory and young fronds collected in the Magellan Strait, Chile. The experiments were carried out during four weeks in controlled conditions of temperature and photoperiod and the results were compared with a control treatment (without UVB). All UVB irradiation treatments caused bleaching and decrease in growth rates of germlings. Additionally, initial upright fronds were not observed in any of the UVB treatments, where as those cultivated in UVB absence developed erect ones in the second week of culture. The young gametophytes exhibited morphological alteration (small number and size of basal ramifications, curling of tips, bleaching and necrosis) and decrease in growth when exposed to UVB radiation. Young fronds collected from the field showed mainly morphological alterations (curling of frond). Morphological alterations in young gametophytes and young fronds of $I$. cordata could be interpreted as a defense against UVB by reducing the area exposed to radiation. However, high level of UVB radiation can produce irreparable damage, such as necrosis, observed in young gametophytes originated in the laboratory. Finally, the UVB effects on early developmental stages of $I$. cordata depend on the UVB irradiance and time of exposition.
\end{abstract}

Key words: Algae, growth, germlings, Magellan Strait, morphology

\section{INTRODUCTION}

The increasing levels of UVB radiation (280-315 $\mathrm{nm})$ reaching the Earth's surface as a consequence of atmospheric ozone depletion have been reported annually since the late 1980s (Farman et al. 1985). This phenomenon affects the Antarctic region and the southernmost part of
South America during spring, when the area of the ozone hole increases and the stratospheric vortex elongates (Kirchhoff et al. 1997, Diaz et al. 2006).

Since ultraviolet radiation also penetrates the water column (Figueroa 2002, Smith et al. 1992), marine 
organisms are exposed to its harmful effects as well. Benthic macroalgae, in contrast to phytoplankton, are fixed and restricted to their growth sites, thus lacking the ability to avoid solar radiation, especially during low tide (Franklin \& Forster 1997). UVB radiation affects marine macroalgae in several ways as shown in numerous publications reviewed by Franklin \& Forster (1997), Xue et al. (2005), and Bischof et al. (2006). Since most of these studies have been focused on adult stages, little is known about the effect of UVR on early stages. The process related to biological effects of UVB is initiated by the photochemical absorption by important biomolecules. High-energy photons at wavelengths of UVB can be absorbed by nucleic acids, lipids, amino acids, chlorophyll and carotenoids (Harm 1980, Diffey 1991, Franklin \& Forster 1997), causing disruption to biochemical and physiological processes such as growth, survival, synthesis of pigments and photoprotective substances, oxygen production, mobility, metabolism of nitrogen, carbon uptake and assimilation (Häder et al. 1995, Sinha et al. 1996, Franklin \& Forster 1997, Jansen et al. 1998, Sinha et al. 1998, Bischof et al. 2002).

Although the UVB effects on the algae physiology are relatively well-documented, morphological alterations caused by UVB are not common in the literature (Bischof et al. 2006). Such studies are necessary because the morphology and integrity of algae present a holistic and integrated indicator of damage occurring on several levels (Roleda et al. 2004, Navarro et al. 2009). Additionally, changes in morphology could be important defense mechanisms for algae (Navarro et al. 2008), especially for early developmental stages, due their vulnerability to environmental stresses when compared to adult macrothalli. Research evaluating the effects of UVB radiation on early developmental stages and spores is not frequent in literature. Early growth forms are of great importance since reproductive structures and the first stages of development are essential for recruitment, especially for species of ecological and economic importance, as their recovery over time depends almost entirely on reproductive ability.

The aim of this study was to evaluate the effects of different irradiances of UVB radiation on different developmental stages of Iridaea cordata. We assessed morphology and growth of germling and young gamethophytes originated in laboratory, and young fronds collected from the field.

Iridaea cordata is a cold adapted red alga occurring from the sub- Antarctic islands and Tierra del Fuego to the Antarctic continent (Wiencke 1990, Cormaci et al.
1992, Wiencke \& Clayton 2002). This alga is an important carrageenan-producing red alga (Craigie 1990), and it has been harvested in the south of Chile, together with other carrageenan algae.

\section{Materials ANd Methods}

\section{Algal material and general Culture conditions} Infertile and tetrasporophytic fronds of Iridaea cordata were collected from the intertidal zone of Posesion Bay $\left(52^{\circ} 13^{\prime} \mathrm{S}, 69^{\circ} 17^{\prime} \mathrm{W}\right)$, Magellan Strait, Chile, and transported to the Centro para la Acuicultura de Recursos Marinos Subantárticos, Departamento de Ciencias y Recursos Naturales, Universidad de Magallanes, where unialgal cultures were established as described by Oliveira et al. (1995). Cultures were maintained in Provasoli's enriched seawater (20 mL L $\mathrm{mL}^{-1}, 31$ psu salinity), which was prepared without tris phosphate (Ursi et al. 2008), in a temperature controlled room at $9 \pm 1{ }^{\circ} \mathrm{C}$ and $55 \mu \mathrm{mol}$ photons $\mathrm{m}^{-2} \mathrm{~s}^{-1}$, photosynthetically active radiation (PAR) provided by Philips TLT $20 \mathrm{~W} / 54$ daylight fluorescent

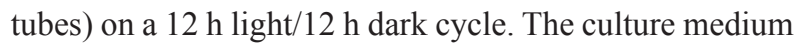
was renewed weekly.

\section{EXPERIMENTAL IRRADIANCE CONDITIONS}

Four treatments were performed: control (only PAR) and three UVB levels (PAR+UVB). In all treatments PAR was $55 \mu$ mol photons $\mathrm{m}^{-2} \mathrm{~s}^{-1}$ on a $12 \mathrm{~h} \mathrm{light} / 12 \mathrm{~h}$ dark cycle during the entire experimental period. Three irradiances of UVB exposure were provided for only $3 \mathrm{~h}$ a day in the middle of the light period (from 11.00 to $14.00 \mathrm{~h}$ ) : 0.17 , 0.5 , and $0.83 \mathrm{~W} \mathrm{~m}^{-2}$ (hereafter UVB1, UVB2, and UVB3, respectively). These irradiances were supplied by two UVB tubes (TL $20 \mathrm{~W} / 12 \mathrm{RS}$, Philips) with peak output at $312 \mathrm{~nm}$. UVC light was filtered with cellulose diacetate foil $(0.075-\mathrm{mm}$ thick), which displayed $0 \%$ transmission below $286 \mathrm{~nm}$. Although the TL 20W/12 RS tubes also emit UVA radiation, the ratio UVB/UVA is higher (1.27) when compared to nature, which is 0.027 for one spring day in Punta Arenas. The UVB values were achieved by varying the distance between the experimental unit (uncovered Petri dishes) and the overhead light source. UVB and PAR were measured using a photometer/ radiometer (Solar Light Company, PMA2200) connected to UVB and PAR detectors (Solar Light PMA2101 and PMA2132, respectively). Daily doses for all treatments are shown in Table 1. 
Table 1. UVB and PAR doses used on Iridaea cordata during 4 weeks of experimentation / Dosis de UVB y PAR utilizadas en Iridaea cordata durante 4 semanas de experimentación

\begin{tabular}{lrrrrrr}
\hline & & \multicolumn{5}{c}{ Doses $\left(\mathrm{KJ} \mathrm{m}^{-2}\right)$} \\
& $\mathrm{W} \mathrm{m}^{-2}$ & 1 day & 1 week & 2 weeks & 3 weeks & 4 weeks \\
\hline Control (PAR) & 11.95 & 516 & 3,097 & 7,227 & 10,841 & 14,455 \\
UVB1 & 0.17 & 1.8 & 11.0 & 25.7 & 38.6 & 51.4 \\
UVB2 & 0.50 & 5.4 & 32.4 & 75.6 & 113.4 & 151.2 \\
UVB3 & 0.83 & 9.0 & 53.8 & 125.5 & 188.2 & 251.1 \\
\hline
\end{tabular}

\section{OBTAINING GERMLINGS AND YOUNG GAMETOPHYTES}

Segments $\left(2 \mathrm{~cm}^{2}\right)$ from tetrasporophytic fronds were cut and placed in Petri dishes with sterile filtered seawater. Petri dishes were kept in a culture chamber until the release of tetraspores. After liberation, tetraspores were collected and put in plastic Petri dishes and cultivated for 2 weeks to obtain germlings (diameter: $0.15 \pm 0.03 \mathrm{~mm}$ ). After that, 30 germlings were cultivated in triplicate in each experimental irradiance condition.

In order to obtain young gametophytes, tetraspores were cultivated for 2 months to reach $1 \pm 0.2 \mathrm{~cm}$ long young gametophytes. After that, 30 young gametophytes were cultivated in triplicate in each experimental irradiance condition.

Additionally, young fronds ( $1 \pm 0.2 \mathrm{~cm}$ long) of Iridaea cordata were collected from the field and placed in plastic Petri dishes. They were cultivated $0.3 \mathrm{~g}$ per plastic Petri dishes.

\section{GROWTH RATES (GR) AND MORPHOLOGY}

The diameter of germlings, the length of young gametophytes and the fresh biomass of young fronds from field were recorded weekly for a period of 4 weeks for GR determination. The GRs were estimated from the following equation: GR \% day ${ }^{-1}=100\left(\ln \mathrm{D}_{\mathrm{f}}-\ln \mathrm{D}_{\mathrm{i}}\right) \mathrm{t}^{-1}$ (Altamirano et al. 2003), where $\mathrm{D}_{\mathrm{i}}$ and $\mathrm{D}_{\mathrm{f}}$ are the initial and final diameter, length or fresh biomass of the germlings, young gametophytes or young fronds (respectively) after $t$ days of culture under different treatments.

In order to analyze changes in morphology, photographs were taken using a stereoscopic microscope and analyzed by Image Pro Plus 4.1 software. In the case of young gametophytes, the new branches originated in each treatment were photographed every week.

\section{Data ANALYsis}

An arcsine transformation was applied to GR percentages. Time series measurements on GR of germlings, young gametophytes and young fronds were subjected to repeated measures ANOVA to determine the effects of treatments across the sampling days. A posteriori Newman-Keuls test was used to establish statistical differences. In all experiments the GR mean value of each Petri dish was considered as a replicate, thus for each treatment the number of replicate was three. All statistical tests were performed in accordance with Zar (1999). Statistical analyses were done using the Statistica 7 software.

\section{Results}

\section{MORPHOLOGY}

Germlings of Iridaea cordata exposed to UVB radiation became paler than those cultivated in control treatment after one week of culture. At the end of the experiment, a necrosis process was observed at the edge of germlings exposed to UVB2 and UVB3 treatments. Moreover, initial upright fronds were not observed in any of the UVB treatments, whereas those cultivated in UVB-absence developed erect ones in the second week of culture (Fig. $1)$.

In regard to young Iridaea cordata gametophytes, all UVB treatments caused morphological changes after the first week of culture. After 2 weeks of culture, a gradual bleaching was observed in apical section of those young gametophytes exposed to UVB2 and UVB3 treatments (Fig. 2), ending in a process of necrosis at the end of the experiment. On the other hand, curling of tips was observed in young gametophytes exposed to UVB1 (Fig. 2). The basal part of young gametophytes exposed to UVB treatment showed shorter and denser branches than those observed in the control treatment (Fig. 3). Also, branches of young gametophytes exposed to control treatment grew faster than those exposed to UVB treatment. 


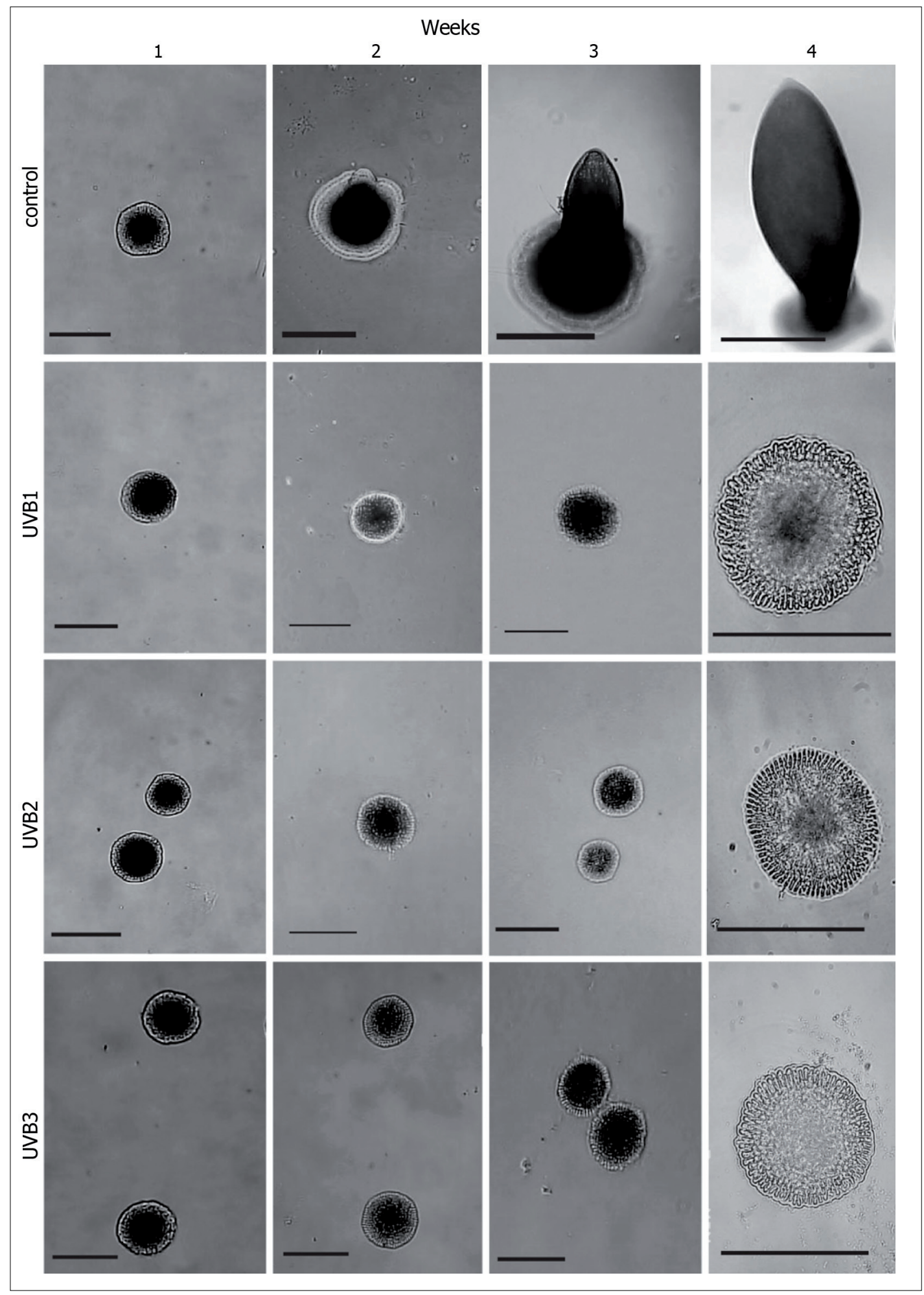

Figure 1. Germlings of Iridaea cordata cultivated under different conditions (UVB1 $=0.17 \mathrm{~W} \mathrm{~m}^{-2}, \mathrm{UVB2}=0.5 \mathrm{~W} \mathrm{~m}^{-2}$, UVB3 $=0.83 \mathrm{~W} \mathrm{~m}^{-2}$ and control $=$ PAR) over a 4 week period. Scale $=0.2 \mathrm{~mm} /$ Germlings de Iridaea cordata cultivados bajo diferentes condiciones (UVB1 $=0,17 \mathrm{~W} \mathrm{~m}^{-2}$, UVB2 $=0,5 \mathrm{~W} \mathrm{~m}^{-2}, \mathrm{UVB} 3=0,83 \mathrm{~W} \mathrm{~m}^{-2}$ y control $=$ PAR) durante un período de 4 semanas. Escala $=0,2 \mathrm{~mm}$ 

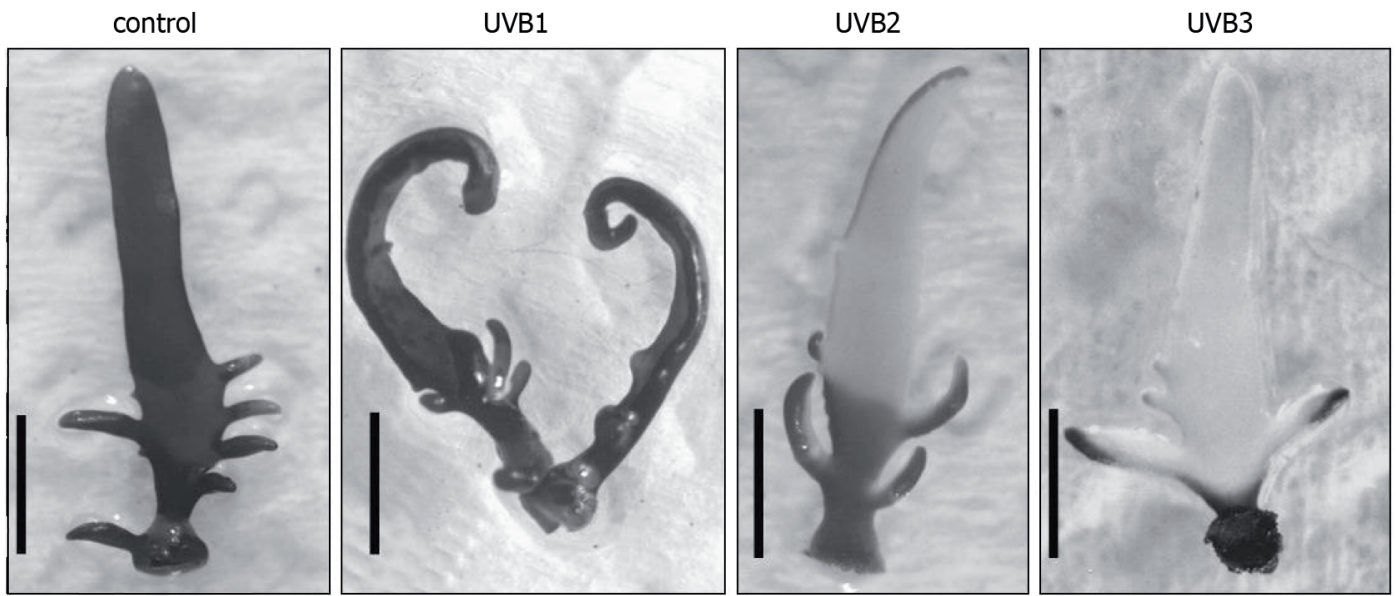

Figure 2. General aspect of young gametophytic of Iridaea cordata generated in laboratory after 4 weeks of culture under different conditions (UVB1 $=0.17 \mathrm{~W} \mathrm{~m}^{-2}$, UVB2 $=0.5 \mathrm{~W} \mathrm{~m}^{-2}$, UVB3 $=0.83 \mathrm{~W} \mathrm{~m}^{-2}$ and control $=$ PAR). Scale $=0.5 \mathrm{~cm} /$ Aspecto general de frondas gametofiticas jóvenes de Iridaea cordata generados en laboratorio después de 4 semanas de cultivo en diferentes condiciones (UVB1 $=0,17 \mathrm{~W} \mathrm{~m}^{-2}$, UVB2 $=0,5 \mathrm{~W} \mathrm{~m}^{-2}, \mathrm{UVB} 3=0,83 \mathrm{~W} \mathrm{~m}^{-2}$ y control $=$ PAR). Escala $=0,5 \mathrm{~cm}$

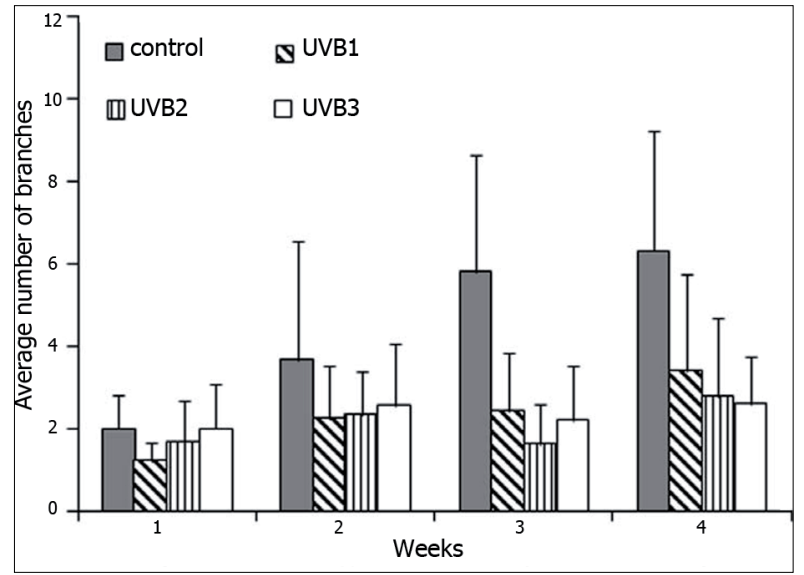

Figure 3. Average number of branches generated by young gametophytic of Iridaea cordata cultivated under different conditions (UVB1 $=0.17 \mathrm{~W} \mathrm{~m}^{-2}$, UVB2 $=0.5 \mathrm{~W} \mathrm{~m}^{-2}$, UVB3 $=0.83$ $\mathrm{W} \mathrm{m}^{-2}$ and control $=$ PAR) in a period of 4 weeks $/$ Número de ramificaciones promedio generadas por frondas gametofiticas juveniles de Iridaea cordata cultivados en diferentes condiciones (UVB1 $=0,17 \mathrm{~W} \mathrm{~m}^{-2}$, UVB2 $=0,5 \mathrm{~W} \mathrm{~m}^{-2}$, UVB3 $=0,83 \mathrm{~W} \mathrm{~m}^{-2}$ y control = PAR) en 4 semanas de cultivo

Young fronds collected from the field also showed morphological alteration when exposed to UVB. This alteration was evident as a curling of the fronds (Fig. 4). However, necrosis was observed only in fronds exposed to UVB3 after 3 weeks of culture.

\section{GrowTH}

Negative effects of UVB on growth germlings and young gametophytes of Iridaea cordata, manly under UVB2 and UVB3 treatments, were observed.
A higher GR was observed in germlings exposed to control treatment when compared with GRs of germlings cultivated under all UVB treatment (d.f $=3, F=305.8, P$ $<0.001$, Table 2, Fig. 5). These differences are attributed not only to the highest diameter in germlings submitted to control condition, but also the fact that these same germlings developed initial upright fronds. These initial upright fronds reached $0.5 \pm 0.02 \mathrm{~mm}$ in height over control condition, meanwhile germlings exposed to all UVB treatment only reached diameters of $0.2 \mathrm{~mm}$. Detailed analysis of the GR of all data collection dates (weeks 1 to 4 ) showed that there was weekly variation (Table 2). Higher GR were always observed in germlings cultivated in control conditions during all the experiment, while germlings submitted to all UVB treatments showed lower GR throughout the experiment, except at week 3, where a small recovery of GRs were observed (Fig. 5).

In regard to young gametophytes of Iridaea cordata originated in the laboratory, no differences in fronds length among any treatment at two weeks of culture were observed (Fig. 6, Table 2). However, at three weeks, young gametophytes grown under control treatment showed higher length when compared with those exposed to UVB treatments (d.f $=3, F=17.4, P<0.001$, Table 2, Fig. 6).

For young fronds from the field, differences in GR were observed when exposed to different UVB treatments (d.f $=3, F=10.8, P=0.003$, Table 2). The post-hoc test indicated that two groups can be established; the UVB2 and UVB3-treated young fronds formed one group defined by low GR, whereas the control and UVB1 treated ones was defined by high GR (Fig. 7). Detailed analysis of the GR 
Table 2. Analysis of variance and Newman-Keuls post hoc test for growth of early development stages of Iridaea cordata exposed to different conditions (UVB1 $=0.17 \mathrm{~W} \mathrm{~m}^{-2}, \mathrm{UVB2}=0.5 \mathrm{~W} \mathrm{~m}^{-2}, \mathrm{UVB} 3=0.83 \mathrm{~W} \mathrm{~m}^{-2}$ and control (C) $=$ PAR). ${ }^{*}$ Indicate significant differences $(P<0.05)$ / Análisis de varianza y test a posteriori de Newman-Keuls para el crecimiento de estados tempranos del desarrollo de Iridaea cordata expuestos a diferentes condiciones (UVB1 $=0,17 \mathrm{~W} \mathrm{~m}^{-2}, \mathrm{UVB} 2=0,5 \mathrm{~W} \mathrm{~m}^{-2}$, UVB3 $=0,83 \mathrm{~W} \mathrm{~m}^{-2}$ y control $(C)=$ PAR $) .{ }^{*}$ Indica diferencias significativas $(P<0,05)$

\begin{tabular}{rcccccc}
\hline Source of variation & Df & $F$ & $P$ value \\
& & \multicolumn{5}{c}{ GR of germlings } \\
Treatment (A) & 3 & 315.3 & $<0.001^{*}$ \\
Time (B) & 3 & 15.1 & $<0.001^{*}$ & & \\
A x B & 9 & 5.3 & $<0.001^{*}$ & & & \\
& C x UVB1 & C x UVB2 & C x UVB3 & UVB1 x UVB2 & UVB1 x UVB3 & UVB2 x UVB3 \\
Total time & $<0.001^{*}$ & $<0.001^{*}$ & $<0.001^{*}$ & $0.035^{*}$ & 0.129 & 0.197 \\
1 week & $<0.001^{*}$ & $<0.001^{*}$ & $<0.001^{*}$ & $0.002^{*}$ & $0.004^{*}$ & 0.598 \\
2 weeks & $<0.001^{*}$ & $<0.001^{*}$ & $<0.001^{*}$ & 0.305 & 0.060 & $0.020^{*}$ \\
3 weeks & $0.002^{*}$ & $0.006^{*}$ & $0.020^{*}$ & 0.325 & 0.101 & 0.279 \\
4 weeks & $0.020^{*}$ & $<0.001^{*}$ & $0.008^{*}$ & 0.099 & 0.234 & $0.017^{*}$
\end{tabular}

GR of Young gametophytes generated in the laboratory

$\begin{array}{rc}\text { Treatment (A) } & 3 \\ \text { Time (B) } & 3 \\ \text { A x B } & 9 \\ & \text { C x UVB1 } \\ \text { 1 week } & 0.945 \\ \text { 2 weeks } & 0.642 \\ \text { 3 weeks } & 0.009^{*} \\ \text { 4 weeks } & <0.001^{*}\end{array}$

$\begin{array}{cc}17.4 & <0.001^{*} \\ 0.7 & 0.542 \\ 6.9 & <0.001^{*} \\ \text { C x UVB2 } & \text { C x UVB3 } \\ 0.945 & 0.384 \\ 0.69 & 0.748 \\ 0.049^{*} & 0.160 \\ <0.001^{*} & <0.001^{*}\end{array}$

UVB1 x UVB2
0.907
0.827
0.917
0.845

$\begin{array}{cc}\text { UVB1 x UVB3 } & \text { UVB2 x UVB3 } \\ 0.380 & 0.598 \\ 0.880 & 0.890 \\ 0.552 & 0.657 \\ 0.144 & 0.223\end{array}$

GR of Young fronds from the field

$\begin{array}{rc}\text { Treatment (A) } & 3 \\ \text { Time (B) } & 3 \\ \text { A x B } & 9 \\ & \text { C x UVB1 } \\ \text { Total time } & 0.759 \\ \text { 1 week } & 0.736 \\ \text { 2 weeks } & 0.828 \\ \text { 3 weeks } & 0.635 \\ \text { 4 weeks } & 0.833\end{array}$

11.5
0.3
2.2
C x UVB2
$0.018^{*}$
0.965
0.059
0.605
0.786

$0.003^{*}$
0.814
0.065
C x UVB3
$0.007^{*}$
0.879
0.195
$0.047^{*}$
0.797

UVB1 x UVB2
$0.012^{*}$
0.694
0.160
0.810
0.988

$\begin{array}{cc}\text { UVB1 x UVB3 } & \text { UVB2 x UVB3 } \\ 0.006^{*} & 0.3032 \\ 0.469 & 0.817 \\ 0.477 & 0.522 \\ 0.078 & 0.217 \\ 0.991 & 0.866\end{array}$

of all data collection dates (weeks 1 to 4) showed that the differences among treatments were evident after week 3 of culture. Observed differences remained between the two groups described above (control-UVB1 and UVB2-UVB3) (Table 2, Fig. 7).

\section{Discussion}

One of the most important results of this study was the inhibition in the development of initial upright fronds from germlings exposed to UVB treatments. This is the first report on this kind of effect caused by UVB in red algae. The initial upright fronds were not developed because the meristematic cells were directly exposed to UVB. Consequently, germlings grew mainly in expansion. However, the cells generated at the edges of the germlings are targets of UVB, in fact necrosis took place at the edges of germlings, where there are fewer layers of cells compared with the center of germlings.

In this study, we used TL 20W/12 RS tubes, which emit mainly UVB radiation and for this reason, we assume that the effect on growth and morphology observed on early developmental stages of Iridaea cordata could be 


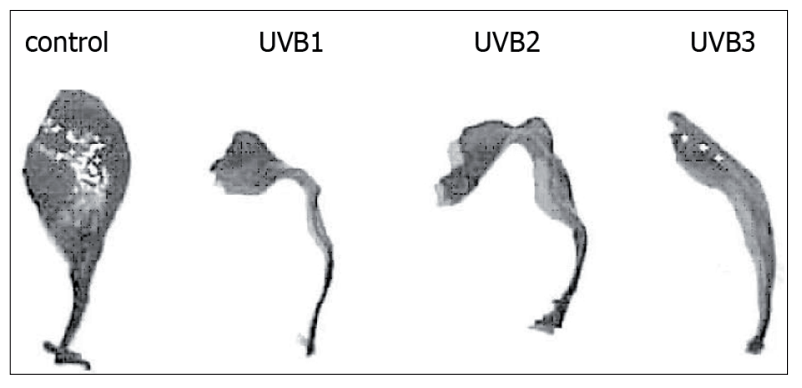

Figure 4. General aspect of Iridaea cordata young fronds from the field after 4 weeks of culture under different conditions (UVB1 = $0.17 \mathrm{~W} \mathrm{~m}^{-2}$, UVB2 $=0.5 \mathrm{~W} \mathrm{~m}^{-2}, \mathrm{UVB} 3=0.83 \mathrm{~W} \mathrm{~m}^{-2}$ and control $=$ PAR). Scale $=1 \mathrm{~cm} /$ Aspecto general de frondas jóvenes de Iridaea cordata provenientes del campo después de 4 semanas de cultivo en diferentes condiciones (UVB1 $=0,17 \mathrm{~W} \mathrm{~m}^{-2}$, UVB2 $=0,5 \mathrm{~W} \mathrm{~m}^{-2}$, UVB3 $=0,83 \mathrm{~W} \mathrm{~m}^{-2}$ y control $=$ PAR). Escala $=1 \mathrm{~cm}$

caused mainly by UVB radiation. However, it is possible that these effects may also be related to the UVA emitted by TL $20 \mathrm{~W} / 12$ RS tubes. It has been reported that high levels of UVA and PAR increase the induction of mechanisms for repairing damage and protection against UVB, also increasing tolerance to UVB (Takayanagi et al. 1994, Franklin \& Forster 1997, van de Poll et al. 2001). Nevertheless UVA also inhibited the growth of embryos of Gigartina skottsbergii Setchell \& Gardner (Navarro et al. 2008), caused a reduction of photosynthetic efficiency in I. cordata tetraspores (Zacher et al. 2009), increased the permeability of chloroplasts membrane (Iwanzik et al. 1983), and caused photoinhibition in 13 red species from intertidal and subtidal of Helgoland (Dring et al. 1996a). In the same way, the UVA radiation was responsible for over $50 \%$ of the total inhibition due to UVR in natural phytoplankton populations from both Antarctic and tropical waters (Helbling et al. 1992). On the other hand, UVA radiation was mainly responsible for a decrease in recruit density and species richness of macroalgal assemblages in Antarctica (Zacher et al. 2007).

In young Iridaea cordata gametophytes exposed to UVB it was observed a delay in development and growth of basal branches, while those present at the beginning of experiment became thicker. Similar alterations have been reported in higher plants and Laminariales algae, where the increase in thickness (concomitant with the decrease in area) was interpreted as mechanism of protection against UVB (Tevini et al. 1981, Barnes et al. 1990, Teramura \& Sullivan 1991, Teramura et al. 1991, Jansen et al. 1998, Michler et al. 2002). In the case of young gametophytes exposed to UVB1, it could make a rearrangement of cells to form denser structures or thick, preventing or reducing the penetration of UVB into innermost cell layers by scattering, absorption and dispersion of radiation (Franklin \& Forster 1997, Swanson \& Druehl 2000).

The morphological alterations caused by UVB in Iridaea cordata, evident as curling of young gametophytes and young fronds, would resemble those changes occurring in leaves of higher plants (reviewed by Greenberg et al. 1997) and macroalgae (Navarro et al. 2008, 2009). This curling could be considered an acclimation process that aims to reduce the area exposed to UVB, thus acting as a mechanism of protection against radiation (Navarro et al. 2008, 2009). Moreover, this defense mechanism would not be related to the energy available for growth. Young gametophytes exposed to UVB1 and young fronds exposed to UVB1 and UVB2 showed morphological changes, while there was no reduction in growth until two weeks of culture. Similar results were obtained for young I. cordata sporophytes (Navarro et al. 2009). This has also been reported for plants where the curling of leaves took place when decrease in growth had not been affected (Greenberg

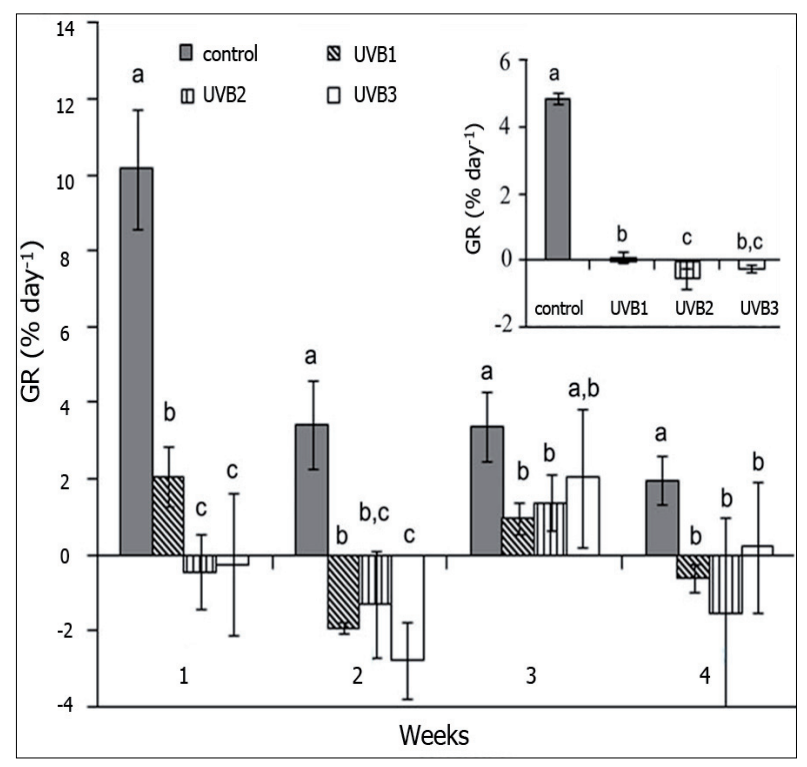

Figure 5. Growth rates of Iridaea cordata germlings grown under different conditions (UVB1 $=0.17 \mathrm{~W} \mathrm{~m}^{-2}, \mathrm{UVB} 2=0.5 \mathrm{~W} \mathrm{~m}^{-2}$, UVB3 $=0.83 \mathrm{~W} \mathrm{~m}^{-2}$ and control $=$ PAR) showing all data collection date (weeks 1 to 4 ). Inset shows growth rates after 4 weeks of cultivation. Values are $\chi \pm s(n=3)$. Treatments with different letters indicate significant differences according to RMANOVA and Newman-Keuls test $(P<0.05)$ / Tasas de crecimiento de germlings de Iridaea cordata cultivados en diferentes condiciones (UVB1 = $0,17 \mathrm{~W} \mathrm{~m}^{-2}, \mathrm{UVB} 2=0,5 \mathrm{~W} \mathrm{~m}^{-2}$, UVB3 $=0,83 \mathrm{~W} \mathrm{~m}^{-2}$ y control $=$ PAR) mostrando todos los datos (semanas 1 a 4 ). El recuadro muestra las tasas de crecimientos después de 4 semanas de cultivo. Los valores son $\chi \pm s(n=3)$. Letras diferentes indican diferencias significativas de acuerdo con RMANOVA y test de Newman-Keuls $(P<0,05)$ 


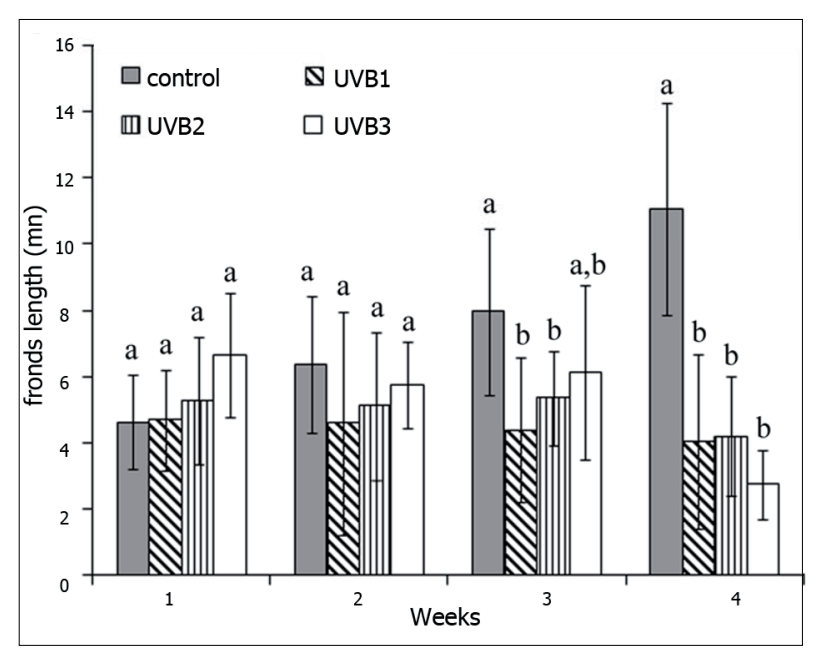

Figure 6. Size of young Iridaea cordata gametophytic fronds cultivated under different conditions (UVB1 $=0.17 \mathrm{~W} \mathrm{~m}^{-2}$, UVB2 = $0.5 \mathrm{~W} \mathrm{~m}^{-2}$, UVB3 $=0.83 \mathrm{~W} \mathrm{~m}^{-2}$ and control $=$ PAR) showing all data collection date (weeks 1 to 4 ). Bars indicate standard deviation $(n=3)$. RMANOVA results are as in Figure 5 / Tamaño de frondas gametofiticas jóvenes de Iridaea cordata cultivados en diferentes condiciones (UVB1 $=0,17 \mathrm{~W} \mathrm{~m}^{-2}$, UVB2 $=0,5 \mathrm{~W} \mathrm{~m}^{-2}, \mathrm{UVB} 3=0,83 \mathrm{~W}$ $\mathrm{m}^{-2}$ y control $=$ PAR) mostrando todos los datos semanales (semanas 1 a 4). Barras indican desviación estándar $(n=3)$. Resultados de RMANOVA como en la Figura 5

et al. 1997, Rozema et al. 1997). Contrarily, Roleda et al. (2004) reported that thalli of Laminaria ochroleuca Bachelot de la Pylaie exposed to UVB showed curling accompanied by reduced growth. In this case, however, decrease in growth was also accompanied by loss of pigments and subsequent necrosis of the thalli.

Pigments represent critical targets of UVB as well. UVB has already been demonstrated to be effective in reducing the concentrations of pigments in different macroalgae (Wood 1989, Grobe \& Murphy 1998, Navarro et al. 2009). The bleaching observed in young Iridaea cordata gametophytes exposed to high irradiances (UVB2 and UVB3) means a destruction of pigments. This bleaching agrees with results observed in adult fronds of I. cordata, in which reduced $\mathrm{PE}$ and PC contents were observed at high doses of UVB (Navarro et al. 2009). Pigment destruction could change the energy initially destined for growth, towards synthesis and reposition of photosynthetic pigments. In fact, bleaching in young I. cordata gametophytes was observed after 2 two weeks of culture and a decrease in growth was detected at three weeks of culture.

Different development stages showed varying responses when exposed to the same UVB doses. At first week (Table 1), the Iridaea cordata germlings exhibited altered growth, young gametophytes showed morphological changes, whereas no effects were observed in young fronds from the field. Based in this fact, we can assume that the germlings and young gametophytes were more sensitive to UVB in the first week of culture. These varying responses could be related not only to the age of the algae (Dring et al. 1996b, Navarro et al.2009), but also to the fact germlings and young gametophytes were originated in laboratory under low PAR. It has been shown that levels of PAR during cultivation are important to the sensitivity of the samples during exposure to UVB (Franklin \& Forster 1997, Swanson \& Druehl 2000). In fact, the germlings previously grown in PAR were more stressed by all UVB treatments, while young fronds were more resistance to UVB because they previously grown under natural solar radiation $(\mathrm{PAR}+\mathrm{UVA}+\mathrm{UVB})$ in the sea. The UVB sensitivity of $I$. cordata could be related to an efficient defense and protection mechanism such as mycosporine-like amino acids (MAAs) that have already been characterized in adults and spores of this species (Hoyer et al. 2001, Zacher et al. 2009). The accumulation of these compounds is induced by both UV radiation (UVA and UVB) and by blue light in the photosynthetic active radiation part of the spectrum (PAR) (Korbe et al. 2006). In this context, young fronds collected from the field may

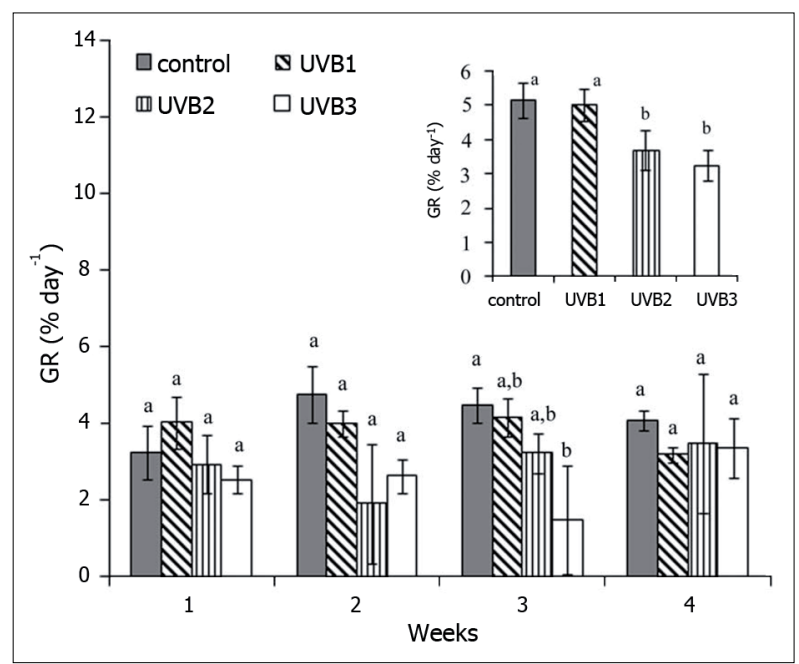

Figure 7. Growth rates of young Iridaea cordata fronds from the field cultivated under different conditions (UVB1 $=0.17 \mathrm{~W} \mathrm{~m}^{-2}$, UVB2 $=0.5 \mathrm{~W} \mathrm{~m}^{-2}, \mathrm{UVB} 3=0.83 \mathrm{~W} \mathrm{~m}^{-2}$ y control $=$ PAR) showing all data collection data (weeks 1 to 4 ). Inset shows growth rates after 4 weeks of cultivation. Values are $\chi \pm s(n=3)$. RMANOVA results are as in Figure 5 / Tasas de crecimiento de frondas jóvenes de Iridaea cordata provenientes del campo cultivados en diferentes condiciones (UVB1 $=0,17 \mathrm{~W} \mathrm{~m}^{-2}$, UVB2 $=0,5 \mathrm{~W} \mathrm{~m}^{-2}$, UVB3 $=0,83 \mathrm{~W}$ $\mathrm{m}^{-2}$ y control = PAR) mostrando todos los datos semanales (semanas 1 a 4). El recuadro muestra las tasas de crecimiento después de 4 semanas de cultivo. Los valores son $\chi \pm s(n=3)$. Resultados de RMANOVA como en la Figura 5 
have had a high concentration of MAAs due to the higher in situ incident light, compared with the artificial laboratory irradiance where the germlings and young gametophytes were originated.

Young Iridaea cordata gametophytes grown under control treatment showed a greater length when compared with those exposed to UVB treatments at three weeks. Contrarily, young I. cordata sporophytes exposed to the same experimental condition showed a decrease in GRs in the beginning of experiments and no differences among any of the treatments were observed in the following weeks of cultivation (Navarro et al. 2009). These facts indicate that different life history phases show varying responses when exposed to the same UVB doses. This could be attributed to the ploidy level of tetrasporophytes (2n) and gametophytes (n). In this context, Roleda et al. (2008) reported that carpospores (2n) of $G$. skottsbergii showed higher tolerance to UV stress than tetraspores (n). Diploid are often thought to have fitness advantage over haploid because the former are able to survive the effect of deleterious recessive mutation on account of their two copies of every gene. However, masking in diploids may be disadvantageous by allowing mutations to persist over time (Roleda et al. 2008). Further exhaustive studies are needed on the UVB susceptibility of young and adult from different life history phases of a specific red macroalgae.

Finally, even if strong PAR and UVA are missing, this study presents a piece of the puzzle about UVB effects on different development stages of Iridaea cordata gametophytes generated in laboratory and collected from the field. Future in situ studies are needed in order to ensure the existence of such alterations mainly in algae species of ecological and commercial importance. In nature, the early developmental stages of macroalgae could grow with the protection of nearby adults. Adult individuals could be attenuating the UVB radiation on young stages, reducing radiation level, which could cause irreparable harm. Nonetheless, if the adults are extracted due their economic importance, the result would be an increase incident radiation producing deleterious effects, especially at midday when irradiance is high and also when macroalgae are exposed during the low tide. On the other hand, an improved understanding of the role of UVB on natural algal populations is needed because it is expected an increase of ultraviolet index by about 3-6\% in southern high latitudes in 2090-2100 (Hegglin \& Shepherd 2009).

\section{ACKNOWLEDGMENTS}

The first author was supported by a CONICYT scholarship. We are grateful to César Cárdenas and José Bonomi, for their suggestions to improve the manuscript. This study was partially financed by the grant No. 26600 (Universidad de Magallanes).

\section{LITERATURE CITED}

Altamirano M, A Flores-Moya \& F Figueroa. 2003. Effects of the radiation and temperature on growth of germling of three species of Fucus (Phaeophyta). Aquatic Botany 15: 9-20.

Barnes PW, SD Flint \& MM Caldwell. 1990. Morphological responses of crop and weed species of different growth forms to ultraviolet-B radiation. American Journal of Botany 77: 1354-1360.

Bischof K, D Hanelt \& C Wiencke. 2002. UV-radiation and Arctic marine macroalgae. In: Hensse D (ed). UV radiation and Arctic ecosystems, pp. 227-243. Springer, New York.

Bischof K, I Gómez, M Molis, D Hanelt, U Karsten, U Lüder, MY Roleda, K Zacher \& C Wiencke. 2006. Ultraviolet radiation shapes seaweed communities. Reviews in Environmental Science and Biotechnology 5: 141-166.

Cormaci M, G Furnari \& B Scamacca. 1992. The benthic algal flora of Terra Nova Bay (Ross Sea, Antarctica). Botanica Marina 35: 541-552.

Craigie J. 1990. Cell wall. In: Cole KM \& RG Sheath (eds). Biology of the red algae, pp. 221-257. Cambridge University Press, New York.

Diaz S, C Camilio, G Deferrari, H Fuenzalida, R Armstrong, C Booth, A Paladini, S Cabrera, C Casiccia, C Lovengreen, J Pedroni, A Rosales, H Zagarese \& M Vernet. 2006. Symposium-in-Print: UV effects on aquatic and coastal ecosystems ozone and UV radiation over southern South America: climatology and anomalies. Photochemistry and Photobiology 82: 834-843.

Diffey B. 1991. Solar ultraviolet radiation effects on biological system. Review in Physics in Medicine and Biology 36: 299-328.

Dring MJ, A Wagner, J Boeskov \& K Lüning. 1996a. Sensitivity of intertidal and subtidal red algae to UVA and UVB radiation, as monitored by chlorophyll fluorescence measurements: influence of collection depth and season, and length of irradiation. European Journal of Phycology 31: 293-302.

Dring M, V Makarov, E Schoschina, M Lorenz \& K Lüning. 1996b. Influence of ultraviolet-radiation on chlorophyll fluorescence and growth in different life-history stages of 
three species of Laminaria (Phaeophyta). Marine Biology 126: 183-191.

Farman JC, BG Gardiner \& JC Shanklin. 1985. Large losses of total ozone in Antarctica reveal seasonal $\mathrm{Cl}_{\mathrm{x}} / \mathrm{No}_{\mathrm{x}}$ interaction. Nature 315: 207-210.

Figueroa FL. 2002. Bio-optical characteristics of Gerlache and Bransfield Strait waters during an Antarctic summer cruise. Deep Sea Research II 49: 675-691.

Franklin L \& R Forster. 1997. The changing irradiance environment: consequences for marine macrophyte physiology, productivity and ecology. European Journal of Phycology 32: 207-237.

Greenberg BM, MI Wilson, X Huang, CL Duxbury, KE Gerhardt \& RW Gensemer. 1997. The effect of ultraviolet-B radiation on higher plants. In: Wang W, JW Gorsuch \& JS Hughes (eds). Plants for environmental studies, pp. 1-35. Lewis Publishers, Boca Raton.

Grobe C \& T Murphy. 1998. Solar ultraviolet-B radiation effects on growth and pigment composition of the intertidal alga Ulva expansa (Setch.) S. \& G. (Chlorophyta). Journal of Experimental Marine Biology and Ecology 225: 39-51.

Häder D, R Worrest, H Kumar \& R Smith. 1995. Effects of increased solar ultraviolet radiation on aquatic ecosystems. Ambio 24: 174-180.

Harm W. 1980. Biological effects of ultraviolet radiation, 216 pp. Cambridge University Press, Cambridge.

Hegglin MI \& TG Shepherd. 2009. Large climate-induced changes in ultraviolet index and stratosphere-to-troposphere ozone flux. Nature Geoscience 2: 687-691 <doi: 0.1038/ NGEO604>

Helbling EW, V Villafañe, M Ferrakio \& O Holm-Hansen. 1992. Impact of natural ultraviolet radiation on rate of photosynthesis and on specific marine phytoplankton species. Marine Ecology Progress Series 80: 89-100.

Hoyer K, U Karsten, T Sawall \& C Wiencke. 2001. Photoprotective substances in Antarctic macroalgae and their variation with respect to depth distribution, different tissues and developmental stages. Marine Ecology Progress Series 211: 117-129.

Iwanzik W, M Tevini, G Dohnt, M Voss, W Weiss, P Gräber \& G Renger. 1983. Action of UV-B radiation on photosynthetic primary reactions in spinach chloroplasts. Physiologia Plantarum 58: 401-407.

Jansen MAK, V Gaba \& BM Greengerg. 1998. Higher plants and UV-B radiation: balancing damage, repair and acclimation. Trends in Plant Science 3: 131-135.

Kirchhoff VWJH, F Zamorano \& C Casiccia. 1997. UVB enhancements at Punta Arenas, Chile. Journal Photochemistry and Photobiology B 38: 174-177.
Korbee N, FL Figueroa \& J Aguilera. 2006. Acumulación de aminoácidos tipo micosporina (MAAs): biosíntesis, fotocontrol y funciones ecofisiológicas. Revista Chilena de Historia Natural 79: 119-132.

Michler T, J Aguilera, D Hanelt, K Bischof \& C Wiencke. 2002. Longterm effects of ultraviolet radiation on growth and photosynthetic performance of polar and coldtemperature macroalgae. Marine Biology 140: 1117-1127.

Navarro NP, A Mansilla \& E Plastino. 2009. Iridaea cordata (Gigartinales, Rhodophyta): responses to artificial UVB radiation. Journal of Applied Phycology 22(4): 385-394 $<$ doi 10.1007/s10811-009-9470-5>

Navarro NP, A Mansilla \& M Palacios. 2008. UVB effects on early developmental stages of commercially important macroalgae in southern Chile. Journal of Applied Phycology 20: 897-906.

Oliveira EC, EJ Paula, EM Plastino \& R Petti. 1995. Metodologías para el cultivo no axenico de macroalgas marinas in vitro. In: Alveal K, M Ferrario, E Oliveira, E Sar (eds). Manual de métodos ficológicos, pp. 429-447. Universidad de Concepción, Concepción.

Roleda MY, K Zacher, A Wulff, D Hanelt \& C Wiencke. 2008. Susceptibility of spores of different ploidy levels from Antarctic Gigartina skottsbergii (Gigartinales, Rhodophyta) to ultraviolet radiation. Phycologia 47: 361370.

Roleda M, D Hanelt, G Krabs \& C Wiencke. 2004. Morphology, growth, photosynthesis and pigment in Laminaria ochroleuca (Laminariales, Phaeophyta) under ultraviolet radiation. Phycologia 43: 603-613.

Rozema J, J van de Staiij, L Björn \& M Cadwell. 1997. UV-B as an environmental factor in plant life: stress and regulation. Trends in Ecology and Evolution 12: 22-28.

Sinha RP, N Singh, A Kumar, HD Kumar, M Häder \& DP Häder. 1996. Effects of UV-irradiation on certain physiological and biochemical processes in cyanobacteria. Journal Photochemistry and Photobiology B 32: 107-113.

Sinha RP, M Klisch, A Gröniger \& DP Häder. 1998. Ultraviolet-absorbing/screening substances in cyanobacteria, phytoplankton and macroalgae. Journal Photochemistry and Photobiology B 47: 83-94.

Smith RC, B Prézelin, K Baker, R Bidigare, N Boucher, T Coley, D Karentz, S Macintyre, H Matlick, D Menzies, M Ondrusek, Z Wan \& J Waters. 1992. Ozone depletion: Ultraviolet radiation and phytoplankton biology in Antarctic Waters. Science 255: 952-959.

Swanson A \& L Druehl. 2002. Induction, exudation and the UV protective role of kelp phlorotannins. Aquatic Botany 73: 241-253. 
Takayanagi S, J Trunk, JC Sutherland \& BM Sutherland. 1994. Alfalfa grown outdoor are more resistant to UV-induced DNA damage than plants grown in a UV-free environmental chamber. Photochemistry and Photobiology 60: 363-367.

Teramura A \& J Sullivan. 1991. Potential impacts of increase solar UV-B on global plant productivity. In: Riklis E (ed). Photobiology, pp. 625-634. Plenum Press, New York.

Teramura A, M Tevini, J Borman, M Caldwell, G Kulandaivelu \& L Björn. 1991. Terrestrial plant. In: UNEP (ed). Environmental effects of ozone depletion, 1991 update. United Nations Environment Programme, Nairobi. [on line] < http://www.ciesin.org/docs/011557/011-557.html>

Tevini M, W Iwanzik \& U Thoma. 1981. Some effects of enhanced UV-B irradiation on the growth and composition of plants. Planta 153: 388-394.

Ursi S, M Guimarães \& EM Plastino. 2008. Deleterious effect of TRIS buffer on growth rates and pigment contents of Gracilaria birdiae Plastino \& E.C. Oliveira (Gracilariales, Rhodophyta). Acta Botanica Brasilica 22: 891-896.

Van de Poll W, A Eggert, A Buma \& A Breeman. 2001. Effects of UV induced DNA damage and photoinhibition on growth of temperature marine red macrophytes: habitat - related differences in UV-B tolerance. Journal of Phycology 37: 30-37.

Wiencke C. 1990. Seasonality of red and green macroalgae from Antarctica. A long-term culture study under fluctuating Antarctic daylengths. Polar Biology 10: 601-607.

Wiencke C \& MN Clayton. 2002. Antarctic Seaweeds, 239 pp. ARG Gantner Verlag, Ruggell.

Wood W. 1989. Photoadaptative responses of the tropical red alga Eucheuma strictum Schmitz (Gigartinales) to ultraviolet radiation. Aquatic Botanic 33: 41-51.

Xue L, Y Zhang, T Zhang, L An \& X Wang. 2005. Effects of enhanced ultraviolet-B radiation on algae and cyanobacteria. Critical Reviews in Microbiology 31: 79-89.

Zacher K, A Wulff, M Molis, D Hanelt \& C Wiencke. 2007. Ultraviolet radiation and consumer effects on a field-grown intertidal macroalgal assemblage in Antarctica. Global Change Biology 13: 1201-1215.

Zacher K, MY Roleda, A Wulff, D Hanelt \& C Wiencke. 2009. Responses of Antarctic Iridaea cordata (Rhodophyta) tetraspores exposed to ultraviolet radiation. Phycological Research 57: 186-193.

Zar JH. 1999. Biostatistical analysis, 663 pp. Prentice-Hall, Upper Saddle River.

Recibido el 17 de julio de 2009 y aceptado el 3 de mayo de 2010 